\title{
PELATIHAN DAN MODELLING IMPLEMENTASI SEKOLAH RAMAH ANAK BAGI GURU- GURU SEKOLAH MENENGAH ATAS
}

\author{
Endang Fauziati ${ }^{1)}$, Suharyanto'), Irwan Nurcholis'1), Amelia Santriane ${ }^{1)}$ \\ 1)Universitas Muhammadiyah Surakarta, Surakarta, Jawa tengah, Indonesia \\ Corresponding author: Endang Fauziati \\ E-mail: endang.fauziati@ums.ac.id
}

\section{Diterima 09 September 2021, Direvisi 17 Desember 2021, Disetujui 17 Desember 2021}

\begin{abstract}
ABSTRAK
Dalam dunia pendidikan, school bullying merupakan salah satu masalah sosial yang cukup memprihatinkan karena terjadi hampir disemua tingkat kelas dan diseluruh dunia. Banyak faktor internal maupun eksternal yang berkontribusi pada school bullying. Pemahaman atas hak-hak anak serta implementasinya dalam Sekolah Ramah Anak merupakan salah satu solusinya. Pengabdian masyarakat ini bertujuan untuk memberikan pelatihan dan modelling tentang Sekolah Ramah Anak. Diharapkan para peserta memiliki landasan konseptual yang komprehensif tentang Sekolah Ramah Anak dan dapat mengimplementasikannya di sekolah masing-masing. Pelatihan dan modelling dilaksanakan melalui aplikasi Zoom, Schoology dan Whatsapp. Setelah pelaksanaan pelatihan, para peserta memiliki pemahaman dasar konseptual yang lebih komprehensif tentang Konvensi Hak-Hak Anak dan implementasinya dalam Sekolah Ramah Anak. Sehingga, mereka mampu berimaji membuat rancangan program implementasi Sekolah Ramah Anak di sekolah masing-masing.
\end{abstract}

Kata kunci: hak-hak anak; sekolah ramah anak; student well-being.

ABSTRACT
In the education world, school bullying represents a social problem that needs excellent attention because it occurs in almost all grade levels across the globe. Many internal and external factors contribute to school bullying. Understanding children's rights and their implementation in Child-Friendly Schools is one of the solutions for the problem. This community service aims to provide training and modelling on Child-Friendly Schools. It is hoped that the participants gain a comprehensive conceptual foundation on Child-Friendly Schools and implement it in their institutions. Training and modelling are carried out through the Zoom, Schoology and Whatsapp applications. The result of the activity indicated that the participants had a more comprehensive conceptual, basic understanding of the Convention on the Rights of the Child and its implementation in Child-Friendly Schools. In addition, they could design programs to implement Child-Friendly Schools in their institution.

Keywords: children's rights; child-friendly schools; student well-being.

\section{PENDAHULUAN}

Fenomena school bullying telah menjadi perhatian para praktisi pendidikan selama dua dekade ini, bahkan kecenderungan semakin meningkat. $\mathrm{Di}$ dunia pendidikan bullying merupakan salah satu masalah sosial yang cukup memprihatinkan karena terjadi hampir disemua tingkat kelas dan diseluruh Negara, termasuk di Indonesia. Bullying merupakan bentuk penindasan oleh seorang individu atau kelompok kepada individu atau kelompok lain, dimana tingkah laku tersebut menyakiti secara psikologis ataupun fisik dan dilakukan secara sengaja dan berulang (Jan \& Husain, 2015). Bullying dapat dilakukan oleh siapa saja, termasuk pimpinan sekolah, guru, staff, murid, orang tua/wali murid, atau bahkan masyarakat.
Faktor yang berkontribusi pada school bullying dapat berasal dari faktor internal maupun eksternal. Faktor internal misalnya berasal dari pendidik sendiri yang tidak memberikan hak-hak anak secara penuh, seperti memberikan hukuman fisik (corporal punishment) dalam rangka pendisiplinan siwa. Faktor eksternal dapat berasal dari lingkungan keluarga, sekolah, maupun masyarakat.

Upaya untuk melindungi hak-hak anak telah dicanangkan melalui Konvensi Hak-Hak Anak (KHA) oleh PBB Tahun 1989, dan Indonesia telah meratifikasinya pada tahun 1990. Indonesia juga telah meratifikasi Undang Undang Perlindungan Anak pada Tahun 2002. Salah satu implementasi dari KHA adalah penyelenggaraan program Sekolah Ramah Anak (SRA). Menurut UNICEF, SRA adalah sekolah/madrasah yang aman, bersih, sehat, 
hijau, inklusif dan nyaman bagi perkembangan fisik, kognisi dan psikososial anak perempuan dan anak laki-laki termasuk anak yang memerlukan pendidikan khusus dan/atau pendidikan layanan khusus.

Rosalin (2015) dalam panduan SRA menyatakan bahwa prinsipnya SRA menjadikan kepentingan dan kebutuhan anak/siswa sebagai pertimbangan utama dalam menetapkan setiap keputusan dan tindakan yang diambil oleh pengelola dan penyelenggara pendidikan. SRA menghormati hak-hak anak dalam mengekspresikan pandangannya tentang ilmu pengetahuan, teknologi, seni, dan budaya, sehingga mereka merasa nyaman dalam proses belajar di sekolah. Relevan dengan hal ini, Iskandar (2015) menyatakan bahwa SRA menjamin kesempatan anak untuk memperoleh hak pendidikan tanpa diskriminasi berdasarkan disabilitas, gender, suku bangsa, agama, jenis kecerdasan, dan latar belakang orang tua. SRA memberikan situasi sekolah yang aman, bersih, sehat, peduli dan berbudaya. SRA melindungi anak dari kekerasan, diskriminasi, dan perlakuan tidak wajar lainnya. SRA menjamin keikutsertaan anak dalam perencanaan, kebijakan, pembelajaran, pengawasan, dan mekanisme pengaduan terkait pemenuhan hak dan perlindungan anak saat menempuh pendidikan.

Hampir seluruh sekolah di Indonesia telah mengadopsi program SRA ini. Namun pemahaman konseptual para guru tentang SRA rata-rata masih dalam tataran folk kwoledge. Artinya, pemahaman para guru masih bersifat tradisional yang belum didasarkan pada perspektif keilmuan yang relevan. Hal ini terlihat dari hasil open ended questionnaire yang diedarkan sebelum pelaksanaan pelatihan ini. Berikut beberapa sample jawaban yang disampaikan para responden: (1) SRA adalah sekolah yang memperhatikan minat dan bakat siswa agar siswa memiliki kemampuan untuk mengekspresikan prestasinya; (2) SRA adalah sekolah yang menyelenggarakan segala aktifitas di lingkungan sekolah, terutama dalam pembelajaran dan mengatasi masalah dengan ramah mnghindari kekerasan, dan eksploitasi pada anak; (3) SRA adalah sekolah tanpa kekerasan yang menerapkan disiplin positif; (4) SRA adalah rumah kedua bagi anak yang harus diciptakan untuk membuat anak merasa senang, nyaman, kerasan di sekolah; dan (5) SRA adalah sekolah yang memberikan pelayanan prima kepada anak agar menjadi anak yang memiliki karakter yang baik, anak terbebaskan dari kekerasan, bullying dan asap rokok.
Relevan dengan topik pengabdian masyarakat ini, yaitu implementasi Sekolah Ramah Anak, maka diharapkan bahwa melalui pelatihan ini, para guru memiliki pemahamam yang komprehensif tentang Sekolah Ramah Anak. Dengan demikian, mereka dapat mengimplementasikan program Sekolah Ramah Anak ini dengan lebih efektif dan variatif. Pelatihan ini dilaksanakan secara daring pada Tanggal 12 Maret 2021 melalui aplikasi ZOOM dan Schoology. Adapun materi pelatihan terdiri dari empat topik utama tentang Sekolah Ramah Anak, yaitu: Konvensi Hak-Hak Anak (KHA), prinsip dasar SRA, karakteristik SRA, dan implementasi SRA di sekolah.

Konvensi Hak-Hak Anak PBB (United Nations Convention on the Rights of the Child) merupakan konvensi internasional yang mengatur hak-hak sipil, politik, ekonomi, sosial, dan kulural anak anak sedunia. KHA ini berisi 54 pasal yang dapat dibagi menjadi tiga kategori, dikenal dengan 3P - provisi, proteksi dan partisipasi (Kanyago et al., 2007: 15). Provisi artinya menyediakan dan memenuhi kebutuhan anak seperti pendidikan, makanan, kesehatan, tempat tinggal, dll.); proteksi artinya melindungi anak (misalnya dari kekerasan fisik, verbal, maupun psikologis, penelantaran, dan eksploitasi); dan partisipasi artinya memberi kesempatan mereka untuk berpartisipasi atau terlibat dalam menentukan kebijakan di masyarakat, khususnya yang melibatkan anak dalam rangka menyiapkan akan menjadi manusia dewasa yang bertanggung jawab.

Prinsip prinsip dasar SRA dikembangkan dari KHA sebagai panduan bagi manajemen sekolah dan kelas (school and classroom management) guna memastikan semua anak memiliki hak untuk memperoleh akses pendidikan dasar yang berkualitas. Model SRA dikembangkan oleh UNICEF sebagai kerangka yang komprehensif dalam mewujudkan pendidikan dengan mempertimbangkan tiga hak anak yang paling dasar yaitu: provisi, proteksi, dan partisipasi. Prinsip dasar SRA meliputi: (1) berpusat pada anak, (2) inclusive, (3) persamaan gender dan menghargai semua latar belakang budaya dan bahasa, (4) effective (dalam arti anak belajar aktif dan dididik (learning and being educated), (5) lingkungan yang protektif, aman, dan sehat, dan (6) anak berpartisipasi secara aktif dan demoktaris. (Hammarberg, 1997)

UNICEF dalam manual untuk SRA menyebutkan ada 13 karakteristik sekolah berbasis hak anak sebagai berikut: (1) Mencerminkan dan menyadari hak-hak setiap anak. (2) Melihat dan memahami anak secara keseluruhan, dalam konteks yang luas. (3) Berpusat pada anak (4) Sensitif gender dan 
ramah terhadap anak perempuan (5) Meningkatkan kualitas hasil pembelajaran (6) Pendidikan diselenggarakan berdasarkan realitas kehidupan anak-anak (7) Fleksibel dan merespon keragaman (8) Bertindak untuk memastikan inklusi, rasa hormat, dan kesetaraan kesempatan bagi semua anak (9) Meningkatkan kesehatan mental dan fisik (10) Menyediakan pendidikan yang terjangkau dan dapat diakses (11) Meningkatkan kapasitas, moral, komitmen, dan status pendidik (12) Perhatian keluarga (13) Berbasis masyarakat (UNICEF, 2016).

Berdasarkan latar belakang tersebut, kegiatan pengabdian tahap awal ini adalah penyampaian materi pelatihan tentang Sekolah Ramah Anak dengan tujuan untuk memberikan pengetahuan berupa konsep dasar tentang Konvensi Hak-Hak Anak PBB dan Sekolah Ramah Anak serta contoh best practice SRA yang telah dilaksanakan oleh dosen-dosen UMS bekerja sama dengan Lund University, Swedia (globalcrconline). Selanjutnya diharapkan para peserta memiliki landasan konseptual yang komprehensig tentang SRA dan dapat mengimplementasikannya di sekolah masing-masing. Pelatihan tentang SRA ini merupakan proses pembekalan konseptual serta pemberian contoh best practice SRA yang sangat diperlukan para guru sebagai modelling dalam mengimplementasikan SRA di sekolah.

Pelatihan dengan modelling ini didasarkan pada teori belajar social (social learning) dari Bandura (1977), yang menyatakan bahwa seseorang individu mengolah informasi atau pengetahuannya sendiri yang diperolehnya melalui pengamatan pada model di lingkungan sekitarnya. Dia merangkai dan menyusun semua informasi tersebut ke dalam kode-kode tertentu dan dilakukan secara berulang-ulang, sehingga mampu memberikan tanggapan aktual. Beberapa hipotesis Bandura antara lain: (1) belajar hakikatnya berlangsung melalui proses peniruan (imitation) atau pemodelan (modeling); (2) individu berperan aktif dalam peniruan dan pemodelan dan dalam menentukan perilaku mana yang akan ditiru dan intensitasnya; (3) dalam peniruan dan pemodelan terjadi penguatan tidak langsung pada perilaku tertentu yang sama efektifnya dengan penguatan langsung; dan (4) mediasi internal sangat penting dalam proses pembelajaran (Nabavi, 2012).

Dengan kegiatan pelatihan dan modelling ini, diharapkan para peserta memperoleh pengetahuan konseptual tentnga KHA dan SRA yang dapat dijadikan pedoman dalam pengembangan dan implemtasi SRA di sekolah. Disamping itu, beberapa contoh best practice yang sampaikan sebagai modelling dapat dijadikan contoh konkrit bagaimana KHA dapat direalisasikan melalui implementasi SRA. Implementasi best practice sebagai modelling ini dapat berfokus pada 3P dalam KHA, yaitu: Provisis, Proteksi, dan Partisipasi. Dengan demikian, materi pelatihan ini dapat memberikan manfaat secara teoretis maupun praktis.

Kegiatan pelatihan ini secara teoritis diharapkan dapat memberikan sumbangan pemikiran (insights) dalam memperluas wawasan konsep dasar tentang SRA. Secara praktis, kegiatan pengabdian masyarakat ini dapat dijadikan bahan masukan (feedbacks) serta modelling bagi guru untuk dapat mengimplementasikan SRA secara efektif sehingga dapat bermuara ke kesejahteraan anak (student well-being). Beberapa modelling dari contoh best practice SRA dijadikan bahan diskusi serta refleksi dalam kegiatan pelatihan ini.

Program SRA telah dicanangkan oleh pemerintah dan panduan SRA telah diluncurkan sejak Tahun 2015 oleh Deputi Bidang Tumbuh Kembang Anak, sebagai salah satu dari empat paket kebijakan SRA (Rosalin, 2015). Dengan demikian, para guru dituntut untuk memiliki kemampuan dalam mengimplementasikan kibajakan SRA ini. Namun, dalam praktiknya masih banyak terjadi proses pendidikan yang menjadikan anak sebagai obyek, kasus kekerasan, pelecehan (bullying), serta model-model hukuman yang tidak mendidik (corporal punishment) pada anak. Untuk itu, implementasi SRA diharapkan dapat mewujudkan sekolah yang aman dan menyenangkan, bebas dari kekerasan. Disamping itu, SRA dapat membentuk perilaku stakeholder kependidikan yang berprespektif anak serta meningkatkan partisipasi anak dalam proses pembelajaran mengajar dan dalam pengambilan keputusan di sekolah. (Rosalin, 2015)

Berdasarkan latar belakang tersebut, maka tujuan pengabdian masyarakat ini adalah untuk memberikan pelatihan konsep dan implementasi Sekolah ramah Anak. Secara rinci pelatihan tini meliputi: (1) pembekakalan tentang prinsip prinsip Sekolah Ramah Anak dan implementasinya; (2) Focus group discussion dan modelling dengan topik bahasan contoh best practice implementasi sekolah ramah anak di beberapa sekolah; dan (3) merancang mini program tentang implemnatsi Sekolah Ramah Anak di masing masing sekolah. 


\section{METODE}

Pelatihan ini secara keseluruhan berjalan lancar dan peserta pelatihan cukup antusias dalam mengikuti program ini. Hal ini terbukti dengan munculnya banyak pertanyaan dan komentar selama sesi interaktif antar peserta dan nara sumber. Beberapa issue yang dapat disampaikan disini anatara lain: (1) konsep dasar tentang SRA belum sepenuhnya difahami; (2) implementasi SRA belum dilaksanakan secara holistic; (3) masih banyak permasalahan di sekolah yang tidak selaras ataupun sejalan dengan KHA dan SRA. Jawaban dan solusi tentang permasalahan ini dibahas tuntas dalam sesi diskusi interaktif dengan peserta. Dari permasalah ini, selanjutnya diskusi dikerucutkan dan diarahkan pada topik utma, yaitu prinsip dasar SRA dan implementasinya di sekolah.

Dengan pelatihan ini, peserta diharapkan memiliki fondasi pemahaman atau keilmuan dasar tentang KHA dan SRA serta implementasinya di sekolah. Dengan memahami konsep dasar tentang KHA dan SRA ini, diharapkan para guru dapat membuat solusi atas permasalahan yang terkait dengan ketidak terpenuhinya hak-hak anak. Para guru memiliki pemahaman mendasar tentang KHA dan SRA, serta strategi mengimplementasikannya di sekolah. Yang perlu digaris bawahi adalah bahwa berbagai komponen kebijakan maupun kegitan di sekolah semestinya bernuara pada student well-being yang hak-haknya harus dihormati dan dipenuhi. Inilah ciri khas dari SRA.

Secara singkat student well-being dirumuskan sebagai sikap, suasana hati, kesehatan, dan kepuasan siswa terhadap diri sendiri serta hubungan dengan orang lain dan pengalamannya di sekolah. Hal ini sejalan dengan Pollard \& Lee (2003) yang meninjau kesejahteraan siswa dari aspek fisik, psikologis, kognitif, sosial, dan ekonomi. Aspek fisik meliputi kesehatan fisik, nutrisi, perawatan tubuh; psikologis terkait dengan kepuasan hidup, resiliensi, dan harga diri; kognitif meliputi prestasi akademik, kemampuan kognitif; sosial meliputi hubungan dengan orangtua dan teman sebaya, serta keterlibatan dalam kegiatan sosial; ekonomi meliputi penilaian terhadap sumber daya ekomomi keluarga.

Sekolah merupakan salah satu lingkungan bagi pertumbuhan dan perkembangan anak, untuk itu aspek student well-being harus menjadi perhatian utama. Mengingat bahwa sebagian besar waktu anak dihabiskan untuk beraktifitas di sekolah sehingga kesejahteraan anak di sekolah dapat berpengaruh pada perkembangan dan pertumbuhan anak secara positif (Soutter et al.,
2014). Kesejahteraan anak di sekolah juga dapat menghindarkan anak tersebut dari perilaku negatif atau menyimpang (Moeller et al., 2020; Na'imah \& Tanireja, 2017).

Salah satu aspek dari student wellbeing adalah berupa kenyamanan hubungan antar personal di sekolah baik, baik hubungannya dengan dengan guru, tenaga pendidik, maupun teman sebaya di lingkungan sekolah. Sebagaimana juga disampaikan oleh Konu et al. (2002) bahwa salah satu aspek dari student well-being di sekolah adalah relasi sosial yang meliputi iklim sekolah, dinamika kelompok, hubungan antar guru-murid, dan hubungan antar teman sebaya. Relasi sosial sebagai sumber dari student well-being perlu dimanaj dengan baik. Dengan kata lain bahwa, student well-being didasarkan pada persepsi dan pengalaman anak di sekolah, maka implementasi program Sekolah Ramah Anak merupakan solusinya. Program ini berupaya untuk menghormati dan memenuhi hak-hak anak dan melindungi anak dari kekerasan. Upaya untuk memberikan rasa aman, nyaman, dan bahagia juga merupakan perwujudan dari student well-being.

Pelaksanaan kegiatan pelatihan dan modelling SRA ini dapat dideskripsikan sebagai berikut. Pelatihan ini diawali dengan acara pembukaan oleh pimpinan prodi pendidikan Bahasa Inggris. Dalam pidato pembukaannya, pimpinan prodi menyatakan bahwa kegiatan pelatihan ini merupakan salah satu kegiatan pengabdian kepada masyarakat yang dilaksanakan secara rutin, sebagai bentuk Dharma Perguruan Tinggi. Program ini dirancang oleh prodi bahasa Inggris untuk memberikan kontribusi nyata bagi sekolah mitra, khususnya dalam mengembangkan sekolah ramah anak.

Kegiatan pelatihan dan modelling kemudian dilanjutkan dengan agenda utama, yaitu sesi presentasi dengan topic Sekolah Ramah Anak: Teori dan Praktik yang disampaikan oleh nara sumber. Secara lengkap materi diberikan dari tataran konsep sampai pada level praksisnya, yang meliputi beberapa topic berikut: (1) konvensi hak-hak anak PBB, (2) konvensi hak-hak anak dan sekolah ramah anak, (3) prinsip prinsip sekolah ramah anak, (4) karakteristik sekolah ramah anak, dan (5) modelling aplikasi SRA di sekolah sebagai contoh best practice, dan (6) refleksi. 


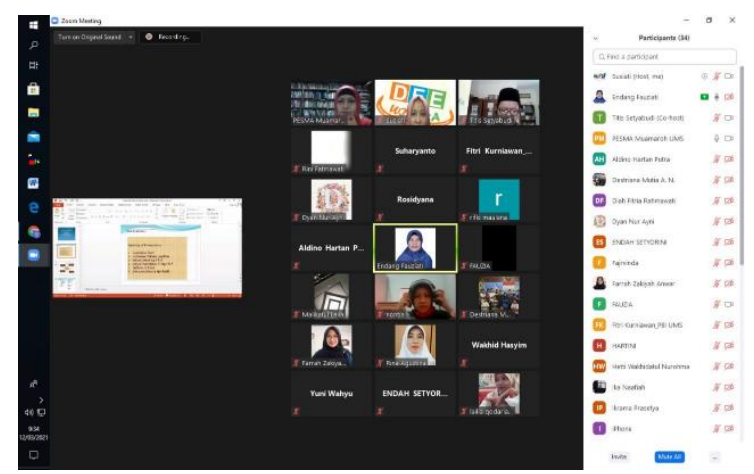

Gambar 1. Pelatihan SRA via Zoom

Adapun beberapa contoh best practice implemenatsi SRA ramah anak adalah sebagai berikut: (1) pengembangan kelas tematik untuk meningkatkan hak partisipasi belajar di sekolah, (2) pengembangan pembelajaran realistik ramah anak untuk membangun rasa empati anak, (3) pengembangan pembelajaran autentik dan partisipatif untuk meningkatkan hak proteksi dan partisipasi anak, (4) pemberdayaan Organisasi Siswa Intra-Sekolah (OSIS) dalam manajemen sekolah untuk meningkatkan proses belajar mengajar, (5) pemberdayaan siswa dalam program pengurangan resiko bencana (PRB). Semua contoh best practice ini merupakan proyek implementasi hak-hak anak di sekolah Muhammadiyah yang dilaksanakan oleh dosen dosen UMS bekerjasama dengan Lund University Swedia. Arsip dapat di temukan di web globalcrconline.org.

Kegiatan pelatihan dan modelling ini diakhiri dengan sesi refleksi dan way forwards. Dalam refleksinya para peserta menyatakan bahwa pemahamannya tentang sekolah ramah anak lebih komprehensif. Sehingga, beberapa ide atau topik program implentasi sekolah ramah anak dapat dilahirkan oleh para peserta. Beberapa diantaranya sangat tertarik pada school bullying dan menawarkan beberapa program sekolah ramah anak untuk mengatasi school bullying sebagai berikut: (1) Mengatasi bullying di sekolah dengan mensinergikan program sekolah dan program parenting, (2) Pengembangan "teacher Care" untuk mengatasi bullying di sekolah, (3) Pengembangan edugame untuk mengurangi school bullying, (4) Pengembangan model disiplin positif dalam pendidikan untuk mengatasi bullying di sekolah, dan (5) Pengembangan pendekatan whole school untuk mengatasi school bullying.

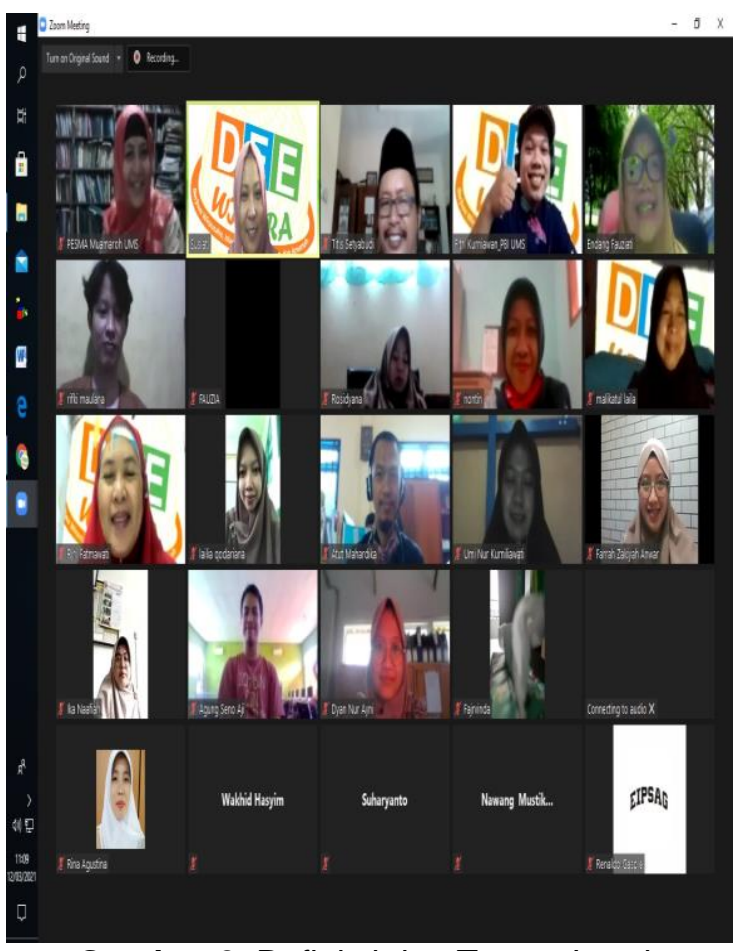

Gambar 2. Refleksi dan Tanya Jawab

Dengan modal pengetahuan yang komprehensif tentang KHA dan SRA, berbagai contoh best practice implementasi SRA, serta ide ide segar berupa topik program implementasi sekolah ramah anak, para peserta menyatakan bahwa mereka merasa lebih siap untuk menghormati dan memenuhi hak-hak anak melalui program sekolah ramah anak. Disamping itu, mereka menyatakan bahwa program pengabdian masyarakat ini telah memberikan manfaat yang signifikan sehingga diharapkan bahwa program ini terus berlanjut dan berkesinambungan. Dengan demikian, hal ini dapat berdampak pada perubahahan positif dalam pengelolaan sekolah yang bermuara pada kesejahteraan anak.

\section{SIMPULAN DAN SARAN}

Kegiatan pengabdian masyarakat ini bertujuan untuk memberikan pelatihan dan modelling tentang implementasi Sekolah Ramah Anak. Hasil interview sebelum pelaksanaan pelatihan, umumnya pemahaman guru masih terbatas pada tataran pengetahuan lokal dan partial saja. Setelah pelaksanaan lokakarya mereka memiliki pemahaman yang lebih komprehensif tentang Sekolah Ramah Anak. Sehingga, mereka mampu berimaji membuat rancangan program implementasi sekolah ramah anak. Pada kesempatan ini, banyak diantara guru yang tertarik pada topik school bullying, dan program implementasi sekolah ramah anak diharapkan dapat mengatasi school bullying yang ada. Guru 
memegang peran yang sangat penting dalam implementasi program sekolah ramah anak karena mereka merupakan agen pembaharu di sekolah. Dengan pemahaman yang komprehensif tentang KHA dan SRA diharapkan mereka mampu menciptakan lingkungan yang kondusif untuk implementasi sekolah ramah anak. Pada akhirnya hak-hak anak dapat dihormati dan dipenuhi yang akhirnya bermuara pada kesejahteraan anak (student well-being).

\section{UCAPAN TERIMAKASIH}

Program pengabdian masyarakat ini dapat terlaksana dengan baik atas dukungan dari Lembaga Penelitian dan Pengabdian Masyarakat Universitas Muhammadiyah Surakarta, Program Studi Pendidikan bahasa Inggris Universitas Muhammadiyah Surakarta, dan Sekolah Mitra.

\section{DAFTAR RUJUKAN}

Bandura, A. (1977). Social learning theory. Englewood Cliffs, NJ: Prentice-Hall

CRC Projects with Child Right Institute at Lund University. Retrieved from http://www.globalcrconline.org/archive

Jan, M. S. A. \& Husain, S. (2015). Bullying in elementary schools: Its causes and effect on students. Journal of Education and Practice, 6(19), 43-56.

Hammarberg, T. (1998). A school for children with rights. UNICEF International Child Development Centre. Retrieved from https://www.peacepalacelibrary.nl/eboo ks/files/357538447.pdf

Iskandar, U. (2015). Pengertian dan Standar Sekolah Sehat. Retrieved from :http://uray-

iskandar.blogspot.co.id/2015/08/pengert ian-dan-standar-sekolahsehat.html? $\mathrm{m}=1$

Kanyago, N. (2007). Realising rights for children. Retrieved from http://www.africanchildforum.org

Konu, A. I., Lintonen, T. P., \& Autio, V. J. (2002). Evaluation of well-being in schools - A multilevel analysis of general subjective well-being. School Effectiveness and School Improvement, 13(2), 187-200.

Konvensi Hak Anak. (1898). Retrieved from http://www.pbhi.or.id/documents/regula si/ KovensiHakAnak.pdf

Moeller, J., Brackett, M. A., Ivcevic, Z., \& White, A. E. (2020). High school students' feelings: Discoveries from a large national survey and an experience sampling study. Learning and Instruction, 66, 1-15.
Na'imah, T., \& Tanireja, T. (2017). Student Well-being pada Remaja Jawa. Psikohumaniora: Jurnal Penelitian Psikologi, 2(1), 1-11.

Nabavi, R. T. (2012). Bandura's social learning theory \& social cognitive learning theory. Retrieved from file://C:/Users/LENOVO/AppData/Local /Temp/BandurasTheory.pdf

Pollard, E. \& Lee, P. (2003). Child well-being: a systematic review of the literature. Social Indicators Research, 61(1), 59-78.

Rosalin, L. N. (2015). Panduan sekolah ramah anak. Kementerian Peberdayaan Perempuan Dan Perlindungan Anak. Retrieved from https://sekolahramahanak.files.wordpre ss.com/2013/11/juknis-final-3-2-161.pdf

Soutter, A. K., O'Steen, B., \& Gilmore, A. (2014). The student well-being model: a conceptual framework for the development of student well-being indicators. International Journal of Adolescence and Youth, 19(4), 496520.

UNICEF. (2016) Child friendly Schools. Retrieved from http://www.unicef.org/lifeskills/ index_7260.html 